\title{
The Implementation of Bill 212 in Ontario Schools: Implications for Black Students
} Hellen Gateri ${ }^{1}$ and Donna Richards ${ }^{2}$

${ }^{1}$ Social Work Program, MacEwan University, Edmonton, Alberta, Canada

${ }^{2} \mathrm{PhD}$ Candidate, York University, Toronto, Ontario, Canada

This is a peer-reviewed (double-anonymized) article

Published online: 1 October 2021

(C) The Author(s) 2021. This article is published with a Creative Commons Attribution license (CC BY 4.0)

https://creativecommons.org/licenses/by/4.0/. It is published with open access at https://inyi.journals.yorku.ca

ISSN: $1929-8471$

DOI: https://doi.org/10.25071/1929-8471.81

Abstract: In February 2008, Bill 212 (Progressive Discipline and School Safety) replaced Bill 81, the Safe Schools Act of June 2000 with regards to the behaviour, discipline, and safety of students. However, since Bill 212 has been in effect, suspensions and expulsions have been unfairly implemented against Black secondary students. Using antiBlack racism (ABR) framework, this commentary paper explores the effects of sections 306-311 of the Bill on Black students within Ontario's secondary school system. Based on this exploration, we will critically examine the way suspensions and expulsions have been employed through Bill 212 and the consequences of these disciplinary measures for Black students. We recommend alternative practices such as restorative justice and the integration of ABR framework to address students' inappropriate behaviours in the educational system.

Keywords: Black youth, Black students, anti-Black racism, student expulsions, student suspensions, secondary school

Abstrait: En février 2008, le projet de loi 212 (Discipline progressive et sécurité scolaire) a remplacé le projet de loi 81, la Loi sur la sécurité dans les écoles de juin 2000 en ce qui concerne le comportement, la discipline et la sécurité des élèves. Cependant, depuis l'entrée en vigueur du projet de loi 212, il y a eu des suspensions et des expulsions injustes envers les élèves noirs de l'école secondaire. En utilisant le document-cadre de lutte contre le racisme AntiNoirs, ce papier de commentaire explore les effets des articles 306 à 311 du projet de loi sur les élèves noirs dans le système scolaire secondaire de l'Ontario. Sur la base de cette exploration, nous examinons de manière critique la façon dont les suspensions et les expulsions ont été utilisées par le biais du projet de loi 212 et les conséquences de ces mesures disciplinaires sur les étudiants noirs. Nous recommandons des pratiques alternatives telles que la justice réparatrice et l'intégration du document-cadre de lutte contre le racisme Anti-Noirs pour éradiquer les comportements inappropriés envers les élèves dans le système éducatif.

Mot Clés: Jeunesse noire, étudiant noirs, racisme Anti-Noirs, expulsion des élèves, suspension des élèves, éducation secondaire.

Corresponding author: Hellen Gateri

Social Work Program, MacEwan University, Edmonton, Alberta, Canada

Email: gaterih@macewan.ca 


\section{Bill 212 and the Negative Impact on Black Students}

The changes brought about by Bill 212, the Education Amendment Act, were meant to ensure that students feel safe at school and on the school grounds (Bill 212, 2007). This paper explores sections 306-311 of Bill 212 by demonstrating how Black students have been negatively impacted by disciplinary measures of suspensions and expulsions within the Ontario school system. Gordon (2017) cited a York University report that found Black children in the Greater Toronto Area (GTA) started kindergarten feeling excited to learn, but many were "gradually worn down" by schools that suspended them at higher rates than other students. The report also found that while academic streaming was supposed to have ended in 1999, Black students were twice as likely to be enrolled in applied courses instead of academic courses compared to their counterparts from other racial backgrounds.

James and Turner (2017) further found that Black students were more than twice as likely as other students to be suspended as least once during high school. Forty-two per cent of Black students had been suspended at least once during high school compared with $18 \%$ of White students and $15 \%$ of other racial groups. Sixty-nine per cent of Black students graduated between 2006 and 2011 compared to $87 \%$ of other nonWhite students and $84 \%$ of White students. The report also cited more recent stats showing that half of the 213 students expelled in the five-year period ending in 201516 were Black. Black students seemed to face an underachievement and opportunity gap in GTA schools (pp. 34-36).

The report further found that Black students in the Toronto District School Board (TDSB) were suspended from school at a greater rate than other students and placed in academic streams below their abilities. Supporting the results of the James and Turner study, Naccarato (2017) reported that almost half of the TDSB's expelled students over the previous 5 years, from 2011 to 2016, self-identified as being Black. A report completed by Chadha et al. (2020) with the Peel District
School Board (PDSB) found that the rate of suspension and expulsion was far greater for racialized students

from elementary to high school-particularly for Black students - than it was for any other student group. From our perspective, these statistics reflect the issues that exist in our educational system and in our society that allow large numbers of students to become disengaged and disconnected from schooling. Noguera (2003) sheds light on this contradiction by explaining how some suspended students understand their education is not going to result in a successful future because of the policies and practices in the education system.

Three published media reports from Draaisma (2017), Naccarato (2017), and McGillivray (2019) indicated the disproportionate rates at which Black students have been suspended and expelled. For example, James (2017, as cited in McGillivray, 2019) confirmed that Black students in the GTA have faced disproportionately high rates of suspensions and expulsions, with at least $42 \%$ of all Black students having been suspended at least once by the time they finish high school. This report further stated that $48 \%$ of Black students, compared to $10 \%$ of White students, were from Toronto public schools. According to one TDSB Executive Superintendent who oversees school programs for students who have been expelled, "systemic issues of race and poverty find their way into the school system" and disrupt the education of many disenfranchised, disadvantaged, and marginalized Black students and other oppressed groups (Naccarato, 2017).

James (2011) asserted that the suspension of Black youth from school is maintained by the ignorance of educators or their refusal to acknowledge how race and racism operate in the gendered construction of Black youth. Dumas and Ross (2016) further argued that Black youth bodies in the school system are viewed as representative of the ultimate threat to authority, and that the disciplining of Black youth is understood as the definitive reinforcement of security and order. Lopez (2019) suggested that the over disciplining of Black youth is an expression of anti-Black racism. Lopez further argued that within the context of anti-Black racism, punishment 
is primary and foundational to Black subjection, with discipline as a popular aspect of cruelty.

\section{Theoretical Framework: Anti-Black Racism and Black Identity}

We centre anti-Black racism ( $A B R$ ) within the Ontario education system by exploring Bill 212, sections 306311 , and how Black students have been impacted by the disciplinary measures of suspensions and expulsions based on its implementation. Clarke, Hasford, Gudge and Mills-Minster (2018) define ABR in the following way:

$A B R$ is that pervasive, overarching climate of attitudes, beliefs, institutional practices, and policies that are embedded in Canada's White supremacist history and culture that denigrate people of African descent, and it is manifested in various forms of structural violence and racialized inequities in multiple social systems, including education, housing, racialized poverty, workplace, and criminal justice (p. 44).

This continuum of racialization accounts for the historical and current processes that have rendered White people as without race while simultaneously creating racial otherness in those who deviate from the White norm.

According to Benjamin (2011, as cited in Lopez, 2019), $A B R$ is a form of racism that is directed against Black people and their resistance to such oppressions. This framework has been used in research on Black youth and education and highlights a unique form of racism against Black people. As Dumas and Ross (2016) pointed out, $A B R$ has become the central focus of how Black people make sense of every aspect of their environment, which is common to the "social, economic, historical and cultural dimensions of their human life" (p. 429).

ABR was first referenced in Canada in 1992 in a government report prepared by Stephen Lewis (1992) on race relations in the province of Ontario. He described ABR this way:

First, we are dealing with, at root, and fundamentally, $A B R$. While it is obviously true that every visible minority community experiences the indignities and wounds of systematic discrimination throughout Southern Ontario, it is the Black community which is the focus. It is Blacks who are being shot, it is Black youths that are unemployed in excessive numbers, it is Black students who are being inappropriately streamed into less academically rigorous programs and are often pushed into sports instead of academics, it is Black kids who are disproportionately dropping out of school, it is housing communities with large concentrations of Black residents where the sense of vulnerability and disadvantage is more acute, it is Black employees, professional and nonprofessional, on whom the doors of upward equity are slam shut. Just as the soothing of multiculturalism cannot mask racism, so racism cannot mask its primary target (p. 2).

In his report, Lewis describes ABR, Black identity, and the racialization of Blackness in various ways, including the experiences of Black people in the Ontario education system.

ABR has been part of Canada's history since the first Black people were enslaved here, and included those who were fleeing slavery in the United States. They were met with $A B R$ by White individuals, White communities, and the government (Maynard, 2017). This history that is not taught in Canadian schools suggests that Black people were treated with hostility in all aspects of society, including education, housing, policing, child welfare, and employment (Maynard, 2017). Without situating $A B R$ within this historical context of the enslavement of African Canadians and acknowledging that ABR is inherently present in Canada, racial inequities can easily be dismissed by blaming Black people for the inequities they experience (Turner Consulting Group \& The Anti-Black Racism Steering Committee, 2021).

Black Canadians include those from a diverse mix of cultures, religions, backgrounds, and identities. Boatswain and Lalonde (2000) pointed out that the term Black is also consistent with the preferences in how Black people label themselves and "may also mitigate against the usage of a term such as African Canadian, which refers to a more distant cultural heritage" (p. 219). Further, James (2011) asserted, "having clarity about 
racial identity labels is important for Black youth because these words are not simply words, we use to identify and differentiate individuals" (p. 468) because the educational outcomes and experiences of Black students are often influenced by gender and race. While the experiences of Black Canadians are diverse, they do have common experiences of $A B R$ that are directed at people of African descent. ABR can combine with other forms of oppression to affect a person's experiences. As such, while people of African descent may be impacted by interpersonal and systemic $A B R$, each person differs in the way they experience and navigate it. Simmons (2020) pointed out that although some Black students may be high achievers, not all will be unaffected by ABR. With these students, the trauma of racism might be unrecognized because Black students' achievements are sometimes mistaken for resilience. Regardless of their own personal experiences, these high-achieving students are also susceptible to vicarious trauma and might be impacted by the emotional residue of the trauma experienced by their Black peers.

\section{Anti-Black Racism and the Education System in Ontario}

In most societies, all school-age children are expected to attend school. However, the public education system in Ontario has countless examples of practices and policies designed to deprive Black children education and to dehumanize Black bodies, practices that arise from the legacy of slavery. Henry (2019) pointed out that in the 1800 s when slavery was legal in Canada, Black children in Ontario were denied education because of their status as property. When the Black population increased because of the arrival of African American freedom seekers in southern Ontario, the practice of excluding Black students in schools became widespread. White parents lobbied the public schools and provincial governments to prevent Black students from attending public schools. Ontario school superintendent Egerton Ryerson responded by implementing the Common School Act of 1850. The act allowed segregation of public schools "based on race and religion" (Henry, 2019, p. 2).

In Ontario the provincial government has a policy that speaks to equity and fairness within all the schools in the province; this implies that all students in the school community are entitled to a respectful, positive school climate and a learning environment free from all forms of discrimination and harassment (The Ontario Public Service, 2014). However, as Maynard (2020) suggests, these schools are also the sites where ABR is reproduced and perpetuated against Black students:

For many Black students, schools are places where they experience degradation, harm, and psychological violence. Even as education environments continue to underserve many communities from different backgrounds, there are unique dimensions to the experiences of Black youth, who experience schools as carceral places characterized by neglect, heightened surveillance, and arbitrary and often extreme punishment for any perceived disobedience (p. 1).

Because Black youth are often not treated as children, schools becomes their first encounter with the organized and systemic devaluation of Blackness in society.

Dei (1997) and James (2011) found that Black students within Ontario schools find the school system oppressive, especially regarding stereotyping by educators. James (2011) asserted that some of these stereotypes include the reference to "African Canadian males as immigrants, fatherless, athletes, troublemakers, and underachievers" (p. 467). These stereotypes construct Black male students as deviant and often influence the way educators deal with their behaviours and rules violations. They are therefore overrepresented in school discipline practices such as time out at the principal's office, suspensions, and expulsions, which then lead to deficient narratives about the moral capacity of Black male students and constrain the public moral imagination of them (Farmer, 2010). As we examine the impact of sections 306-311 of Bill 212 on the experiences of Black students within Ontario's secondary school system, we also discuss some pitfalls with its implementation and suggest other practices to remedy how suspensions and expulsion of these Black students are managed.

\section{Bill 212: Suspensions and Expulsions}

Sections 306-311 of Bill 212 state that teachers are no longer permitted to suspend students and principals are no longer authorized to expel students. However, 
principals can suspend students if they believe that the students have engaged in any of the following activities listed in section 306 (1):

uttering threats to inflict bodily harm on another person, possessing alcohol or illegal drugs, being under the influence of alcohol, swearing at a teacher or another person in a position of authority, committing acts of vandalism, bullying, and other activities under the board's policy" (p. 2).

In addition, the student ought to have engaged in these activities while at school, at a school-related activity, or in other circumstances whereby engaging in any of these activities must have an impact on the school climate (Bill $212,2007)$. The Bill increased the list of mitigating factors that must be considered before imposing discipline. For example, if a school principal decides to suspend a student for engaging in any of the activity described above, the student is suspended from engaging in all school-related activities. A suspension under this section shall be for no less than one school day and no more than 20 school days. The principals are expected to assign suspended students to a program for suspended students. A principal may not suspend a student under section 306 more than once for the same occurrence (Bill 212 , pp. 2-3). Roher (2007) noted that mitigating factors are given more weight in decision processes about suspension and expulsions. School boards are also required to have alternative programs available to their expelled and suspended students, and to readmit expelled students after they have completed these programs. Furthermore, Réaume and Fogels (2008) found that these students remain students of the board during the expulsion period. However, expelled students who wish to return to school are required to have satisfactorily completed the program for expelled students.

\section{The Pitfalls with the Implementation of Bill 212, Sections 306-311}

The changes in sections 306-311 are intended to represent fundamental changes in the treatment of suspended and expelled students, moving away from rejection and isolation to education initiatives that address each student's particular needs. However, to date this intent has not been fully realized. Roher (2007) addressed the concern that some school administrators might choose to use inappropriate methods to discipline students because of the complexities and additional workload introduced by Bill 212. Roher predicted that noncompliance could include "de-admitting" students from their schools and attempting to remove students from their school register (p. 221). In 2009, an investigation by the Toronto Star found that some students had entered what they termed as "suspension limbo" and were being excluded informally so that they did not show up on the school board statistics. In addition, some principals were setting conditions for return to school so high that expelled students were being thrown out of school for the rest of their high school years (Rankin \& Contenta, 2009). Disciplinary practices such as these are problematic because they do not reflect the mitigating factors that are recommended by the changes in Bill 212, sections 306-311 to support students.

These inconsistences were also observed by Chadha et al. (2020) in their review of the Peel District School Board (PDSB), which found that most racialized students have been suspended and expelled on punitive grounds, for example, for wearing a hoodie, wearing hooped earrings, and talking back. This report indicated that Black students are not included in progressive disciplinary measures and school administrators tend to escalate trivial issues without considering the recommended mitigating factors, which leads to suspensions or expulsions and further stigmatization of Black youth. Interestingly, it appeared to us that school administrators use their discretionary power in their disciplinary decision making. How they choose to exercise this discretion seems to be based on their own value systems, preferences, and assumptions that do not consider a progressive discipline regime, defined as a "series of defined steps progressively applied as disciplinary interventions to improve student behavior" (Roher, 2007, p. 217).

From our perspective, Bill 212, sections 306-311, outlines clear procedures and guidelines for school boards and administrators to follow regarding suspensions and expulsions; however, a glaring omission in the Bill is that there is currently nothing that holds 
school administrators answerable for violations of the Bill. However, Bill 212 asserted that students who may have been unjustly suspended or expelled have a right to appeal within 10 days by providing a written notice on their intention.

One of the mitigating factors under Bill 212 requires school boards to provide programs for suspended and expelled students before imposing discipline. School boards are expected to coordinate the types of support required to assist their suspended and expelled students to continue with their learning (Roher, 2009). However, Goodes (2016) pointed out that the Ministry of Education funding has failed to meet these requirements. Over the years, Toronto public school boards have seen funding cuts for alternative programs, additional assistance from various professionals and community agencies, and professional development for teachers. In a study on Ontario safe school policy and racialized students, Hussain (2015) found that some school boards had only one or two alternative programs, and these were geographically located in areas that were inaccessible or challenging to access for students who were suspended or expelled from mainstream schools. As a result, students who were referred to these programs did not attend because they found it timeconsuming and expensive to travel to the program location.

Winton (2012) reported that suspension and expulsion programs have not been very effective because many students who attend them do not return to mainstream schools. She suggested that suspension and expulsion programs need to be evaluated to support students' needs and their return to mainstream schools. In our view, it is critical for funding to be provided to school boards to support programs for suspended and expelled students. This funding could also be used to support students who demonstrate behavioural problems that could lead to suspension.

Funding cuts have also resulted in limited time spent by school principals and teachers on professional development to challenge their practices, beliefs, and knowledge about Black and other racialized students (Goodes, 2016). Inadequately trained principals and teachers are less effective in their effort to teach and support students from diverse backgrounds and needs who require their ongoing support.

We argue that more resources are needed to provide support to students, but also to support professional development for classroom teachers and principals. The value of additional support for classroom teachers from a multitude of other professionals - educational assistants, social workers, psychologists, child and youth workers, and others - cannot be understated. Yet without adequate funding, these are the first people who are cut from school budgets. It is disturbing when many of the students who are expelled or suspended are students of colour (especially Black students) who are left to languish during their suspensions. It is also interesting to note, from our viewpoint, that school boards are spending limited funds on alternative programs, additional assistance from various professionals, and professional development for staff, while parents and communities are simultaneously being told that schools are running shortfalls and therefore are unable to address ABR concerns. From our perspective, local communities and Black parents have been frustrated by what they see as discursive manipulations by school boards and administrators.

\section{Recommendations for Practice}

We recommend that educators across Ontario should become engaged with the praxis of restorative justice to address students' inappropriate behaviours. As demonstrated in this paper, exclusionary disciplinary practices such as suspensions and expulsions are detrimental to students' success and school climate. Bill 212 was intended to move schools away from notions of mandatory suspensions and expulsions by implementing restorative practices. The Durham District School Board Safe Schools initiative (2012, as cited by the Zheng \& De Jesus, 2018) asserted that restorative practices have their roots in the cultural traditions of Indigenous people around the world who seek to "live and learn in a good way with each other, value harmony, and respect" (p. 4). According to Pakan and The Society for Safe and Caring Schools and Communities (2007), restorative practice has been defined by the Correctional Services of Canada as a "non-adversarial, non-retributive approach to justice that emphasizes healing in victims, meaningful 
accountability of those responsible for harm, and the involvement of citizens in creating healthier and safer communities" (p. 2). Restorative justice works to repair the damage and promote healing and growth (Pakan \& The Society for Safe and Caring Schools and Communities, 2007). Students' inappropriate behaviours can be addressed by emphasizing "corrective and supportive disciplinary measures in a manner that promoted positive behaviors" (Milne \& Aurini, 2017, p. 31) through prevention programs, interventions, and other supports. Through restorative practices, the Bill opened the door for a progressive discipline approach (for example, prevention and early intervention) in cases of student misconduct, and through the provision of programs and supports for successful integration of suspended and expelled students back into the school system (Zheng \& De Jesus, 2018).

According to the Zheng \& De Jesus (2018) report, the TDSB has been gradually introducing restorative practices into its schools for more than 12 years as one of the follow-up intervention strategies for suspended students and for teachers' professional learning. The report further asserted that although the number of suspensions at TDSB schools declined over time, when restorative practices were implemented the proportion of suspensions increased steadily from less than $1 \%$ in the 2006-2007 school year to $18 \%$ in the 2016-2017 school year (Zheng \& De Jesus, 2018, p. 18). However, some regions in Ontario have demonstrated effective implementation of restorative practices in the school system. For example, the Lakehead District School Board revealed positive implementation of restorative practices at three schools which decreased the number of suspensions and enhanced students' positive attitudes towards learning (Lewington, 2016, as cited by Zheng \& De Jesus, 2018). In our opinion, there is need to provide ongoing professional development to principals and teachers so that they can learn to engage with restorative practices when dealing with students' inappropriate behaviours. Studies are needed to fully understand the effects of restorative practices on suspended students based on their cultural and ethnoracial background, school discipline history, and previous academic achievement.
It is our contention that the educational system needs to engage in conversation about $A B R$, since the language of diversity, inclusion, and equity is often used to avoid conversations about racism and how deeply embedded it is within the education system. Turner Consulting Group and The Anti-Black Racism Steering Committee (2021) suggested that engaging in these conversations could increase the capacity of educators to meaningfully integrate racial literacy in the curriculum. Racial literacy is central to teachers' ability to teach and support Black students. It also enhances their understanding of the ways racism and white supremacy operate and are woven into the fabric of society's institutions, which could help educators to see and respond to disciplinary actions. Sibblis (2014) indicated that racial literacy also helps educators to understand that the current disciplinary measures contain and oppress racialized bodies, such as Black students. From our perspective, developing racial literacy requires the difficult and uncomfortable work of exploring one's own racial identity, reflecting on the racist views one holds, and understanding one's role in perpetuating poor outcomes for Black students. Moscovitch (2020) asserted that integrating racial literacy in the education system means that White educators and staff will be reflecting on Whiteness, White dominance, and White supremacy and how it is tied to anti-Blackness. Racialized educators and staff will also be doing the hard work of reflecting on how they uphold Whiteness within their working and learning environments and how $A B R$ is perpetuated within their communities.

According to Turner (2014), integrating racial literacy in the curriculum requires teacher education programs to become explicitly anti-racist to ensure that new teachers are taught about creating anti-racist and Black-affirming learning environments to eliminate suspensions and expulsions of Black students. It is our perspective that this teaching practice could also help school boards to hire employees who are equipped and committed to creating anti-racist working and learning environments. Further, school boards need to commit to providing ongoing professional development to their existing employees about White supremacy, ABR, and antiracism to prepare teachers and administrators to lead difficult conversations with students, parents, and staff 
within their school communities. This way teachers will be prepared to disrupt and address racism in the classroom when it does occur, because not talking about race further invalidates the real-world experiences of Black students and retraumatizes them.

Open Access This article is distributed under the terms of the Creative Commons Attribution License (CC BY 4.0, https://creativecommons.org/licenses/by/4.0/) which permits any use, distribution, and reproduction in any medium, provided the original author(s) and the source are credited.

${ }^{*}$ The authors have no conflicts of interest to disclose.

\section{References}

Bill 212, An Act to amend the Education Act in respect of behaviour, discipline and safety, 2007, 2nd Session, 38th Legislature, Ontario, 2007.

Boatswain, J. S., \& Lalonde, R. (2000). Social identity and preferred ethnic/racial labels for Blacks in Canada. Journal of Black Psychology, 26(2), 216-234.

Chadha, E., Herbert, S., \& Richard, S. (2020, February 28). Review of the Peel District School Board [Letter to the Honourable Stephen Lecce, Minister of Education]. http://www.edu.gov.on.ca/eng/new/review-peeldistrict-school-board-report-en.pdf

Clarke, J., Hasford, J., Gudge, L., \& Mills-Minster, S. (2018). Imagining a community-led, multi-service delivery model for Ontario Child Welfare: A framework for collaboration among African Canadian community partners. Journal of Law and Social Policy, 28(1\&2), 42-66.

Dei, G. J. S. (1997). Race and the production of identity in the schooling experiences of African- Canadian youth. Discourse. Studies in the Cultural Politics of Education, 18(2), 241-257.

Draaisma, M. (2017, April 24). Black students in Toronto streamed into courses below their ability, report finds. CBC News.

https://www.cbc.ca/news/canada/toronto/study-blackstudents-toronto-york-university-1.4082463
Dumas, J. M., \& Ross, M. K. (2016). "Be real black for me": Imagining BlackCrit in education. Urban Education Journal, 51(4), 415-442.

Farmer, S. (2010). Criminality of Black youth in inner-city schools: "Moral panic," moral imagination, and moral formation. Race, Ethnicity and Education, 13(3), 367381.

Goods, W. (2016). Progressive discipline. Mitigating circumstances and the austerity agenda. VOICE. The Magazine of the Elementary Teachers Federation of Ontario. https://etfovoice.ca/feature/progressivediscipline/page/0/1

Gordon, A. (2017, April 25). Black students hindered by academic streaming, suspension, says report from York University. Toronto Star.

https://www.thestar.com/yourtoronto/education/2017/ 04/24/black-students-hindered-by-academic-streamingsuspensions-report.html

Henry, N. (2019, May 19). Anti-Black racism in Ontario schools: A historical perspective. [Research and Policy Brief No.1]. Turner Consulting Group Inc. policy_brief__no_1_may_2019.pdf (weebly.com)

Hussain, S. A. (2015). The effects of Ontario's safe schools' policy on racialized students (2000-2013). [Doctoral dissertation, Queen's University] Hussain_Shaheeda_A_201509_PhD.pdf; sequence=1 (queensu.ca)

James, C. (2011). Students "at risk": Stereotypes and the schooling of Black boys. Urban Education Journal, 47(2), 464-494.

James, C., \& Turner, T. (2017). Towards race equity in education: The schooling of Black students in the Greater Toronto Area.

https://edu.yorku.ca/files/2017/04/Towards-RaceEquity-in-Education-April-2017.pdf

Lewis, S. (1992, June). Report of the advisor on race relations to the Premier of Ontario Bob, Rae.

https://www.siu.on.ca/pdfs/report of the advisor on $r$ ace relations to the premier of ontario bob rae.pdf

Lopez, A, E. (2019). Anti-Black racism in education: School leaders' journey of resistance and hope. In R. Papa (Ed.), Handbook on promoting social justice in education (pp. 
1935-1950). Springer International.

https://doi.org/10.1007/978-3-030-14625-2

Maynard, R. (2017). Policing Black lives. Devaluing Black life, demonizing Black bodies. Fernwood Publishing.

Maynard, R. (2020, June 10). Canadian education is steeped in anti-Black racism. The Walrus.

https://thewalrus.ca/canadian-education-is-steeped-inanti-black-racism/

McGillivray, K. (2019, March 3). A road map for black parents navigating bias in the school system. CBC News. https://www.cbc.ca/news/canada/toronto/carl-jamesinformation-sheets-1.5067841

Milne, E., \& Aurini, J. (2017). A tale of two policies: The case of school discipline in an Ontario School Board. Canadian Journal of Education Administration and Policy, 183, 30-43.

Moscovitch, P. (2020, July 24). Anti-Black racism in schools: Still a long way to go. Halifax Examiner.

https://www.halifaxexaminer.ca/province-house/antiblack-racism-in-schools-still-a-long-way-to-go/

Naccarato, L. (2017, April 11). Almost half of the TDSB students expelled over the last 5 years are black, report says. CBC News.

https://www.cbc.ca/news/canada/toronto/almost-halfof-tdsb-students-expelled-over-last-5-years-are-blackreport-says-1.4065088

Noguera, P. A. (2003). Schools, prisons, and social implications of punishment: Rethinking disciplinary practices. Theory into Practice,42(4), 341-350.

Pakan, N., \& The Society for Safe and Caring Schools and Communities (2007). Restorative justice community/classroom conferencing: A guide for parents and teachers. Alberta Solicitor General and Public Security.

http://www.restorativeschoolstoolkit.org/sites/default/fi les/Restorative-Justice-booklet-Web-version 0.pdf

Rankin, J., \& Contenta, S. (2009). Suspended sentences: Forging a school-to-prison pipeline? Toronto Star. https://www.thestar.com/news/gta/2009/06/06/suspen ded sentences forging a schooltoprison pipeline.html

Réaume,V., \& Fogels, J. (2008). From "zero tolerance" to progressive discipline: Ontario's Bill 212. Education leadership today and tomorrow: The law as friend or foe. https://www.cavalluzzo.com/docs/defaultsource/publications/2008-04-20-from-zero-tolerance-toprogressive-discipline-ontario s-bill-212---educationlaw.pdf?sfvrsn=87f255d5 2

Roher, E. M. (2007). Will safe schools legislation make Ontario schools safer? Education and Law Journal, 17(1), 203-221.

Roher, E. M. (2009, February 24). Has Bill 212 made Ontario schools safer? Lexology. https://www.lexology.com/library/detail.aspx?g=48a095 09-619b-4232-ab53-1f51749a1f0a

Sibblis, C. (2014). Expulsion programs as colonizing spaces of exception. Race, Gender, \& Class, 21(1/2), 64-81.

Simmons, D. (2020). Confronting trauma/the trauma we don't see. Education Leadership, 77(8), 1-3.

The Ontario Public Service (2014). Equity and inclusive education in Ontario schools. Guidelines for policy development and implementation.

http://www.edu.gov.on.ca/eng/policyfunding/inclusiveg uide.pdf

Turner Consulting Group \& The Anti-Black Racism Steering Committee. (2021). Dismantling Anti-Black racism strategy: Creating anti-racist and Black-affirming learning and working environment. Part1: Background report. York Region District School Board.

https://www2.yrdsb.ca/sites/default/files/2021-03/ABRSTRATEGY-Part1.pdf

Turner, T. (2014, October 30). Teacher diversity gap. Turner Consulting Group.

https://www.turnerconsultinggroup.ca/blog/teacherdiversity-gap

Winton, S. (2012). From zero tolerance to students success in Ontario, Canada. Education Policy, 27(3), 467-498.

Zheng, S., \& De Jesus, S. (2018, January). Effects of restorative practice on suspended pupils' school engagement, academic achievement, and postsecondary destinations. Research \& Information Services, Toronto District School Board.

https://www.tdsb.on.ca/Portals/research/docs/reports/ RestorativePracticesStudy2006-07to2016-17.pdf 


\section{INYI Journal}

Editor-in-Chief: Nazilla Khanlou Managing Editor: Luz Maria Vazquez York University, 4700 Keele Street Toronto, ON, Canada, M3J 1P3 Website: https://inyi.journals.yorku.ca/ Email: inyi.journal@gmail.com

Follow us at: https://twitter.com/YorkUOWHC ISSN 1929-8471 